\title{
Identifying the Influential Factors on Social Impact Assessment of Reconstruction Projects in Historic Site - A Case Study on Jameh Mosque Street, Yazd, Iran
}

\author{
Mohammad Nasir Tighsazzadeh \\ Department of Urban and Regional Planning \\ Shahid Beheshti University, Tehran, Iran
}

\begin{abstract}
Social impact assessment (SIA) is a process that provides a framework for gathering and analyzing information to determine intended and unintended social consequences of changes and developmental interventions on human environment. This assessment that emphasize on social and cultural issues, is more important in historic site that have more tangible social role than the new parts of the city and these areas should preserved by planning and subsequent evaluations due to their cultural heritage value. The aim of this paper that evaluated social impacts of reconstruction project of Jameh Mosque Street of Yazd city in Iran when it came into operation, is identify specific indicators for SIA in historic site through the use of general indicators and matching SIA process to the historical and cultural context of the heritage site. In order to achieve this goal, the research is based on SIA approach also descriptive and inferential statistics and focus group methodology were used to analyze the environment data. Hypotheses and measuring variables tested by analytic hierarchy process (AHP) and qualitative analysis with domain matrix. Accordingly, the estimation and selection of the effects of the project and its prioritization are based on some factors such as the importance and degree of feasibility that have different result in heritage site than the new urban areas. Finally, an operational framework and some strategic suggestions were made to improving the general process of SIA to use in heritage site and maximizing the efficiency of similar projects in every historic areas which leads to the consent of stakeholders.
\end{abstract}

Keywords: Social Impact Assessment (SIA), Historic site, Culture, Yazd.

\section{Introduction}

In terms of Armour, social impacts are changes that occur in people's life style, culture including customs, beliefs, values and the last one in society (Armour, 1992). The Inter-organizational Committee on Guidelines and Principles for Social Assessment (1994) (cited in Glasson 2000) defined social impacts as 'the consequences to human populations of any public or private actions that alter the ways in which people live, work, play, relate to one another, organize to meet their needs, and generally cope as members of society'. The purpose of urban rehabilitation projects is to improve the physical and spatial quality. Physical changes are very tangible, but changes such as economic, social and environmental are not easy to understand. Changes that have far greater effects than physical changes. On the other hand, if these changes occur in a sensitive environment, it will have far more impact. The environment-sensitive, valuable environments that are highly vulnerable to various reasons.

Thus, this paper presents a list of significant factors to access the social impacts of revitalizing and reconstruction projects in historic site, using specific part of Yazd as a case study of dense urban city facing redevelopment plans after UNESCO inscribed the city on world heritage list.

\section{Social impact assessment - the origins, definition and necessity}

In the 1970s, the origins of social impact assessment come from the Environmental impact assessment (EIA) model in the USA (Bryan, 2009). This method emerged to assess the impacts on society of the projects before they go ahead. Though today pre-conflict, in-conflict and post-conflict are as three possible SIA time point (Barrow, 2010).

Although there is no unique definition of SIA, it can be understood from description of individuals, groups and communities. In a research context, social impact assessment is a sub-field of the integrated social sciences that is developing a knowledge base to allow a systematic appraisal of impacts on the day-to-day quality of life of persons and communities whose environment is affected by a proposed policy, plan, program or project (Burdge, 1999: 4) also Vanclay knows social impact assessment as a process to managing the social issues related to planned intervention (Vanclay 2003a, 2006).

The Inter-organizational Committee on Guidelines and Principles for Social Assessment (1994) (cited in Glasson 2000) defined social impacts as 'the consequences to human populations of any public or private actions that alter the ways in which people live, work, play, relate to one another, organize to meet their needs, and generally cope as members of society' (The Inter organizational Committee on 
Guidelines and Principles, 1994: 1).

Reconstruction and reviving projects can be seen as a strategy focusing on the physical improvement but has direct and indirect effects not just on the physical. The historic site is not only preserved for its historical and architectural values, but also for rich identity and social values that are brighter than the new parts of the city (Swensen, 2012).

\section{Methodology}

Research is based on SIA approach also descriptive and inferential statistics and focus group methodology were used to analyze the environment data. Hypotheses and measuring variables tested by analytic hierarchy process (AHP) and qualitative analysis with domain matrix. The survey method of research is performed using data collection tools such as observation, interview and questionnaires. It is necessary to determine the sample size of statistics. Accordingly, the sample size is 80 questionnaires using Cochran's formula. 58 questionnaires were distributed among residents and 22 questionnaires distributed among the shopkeepers of Masjed Jameh Street. In order to resolve the probable problems of the questionnaire and to ensure its comprehensibility, a preliminary draft was carried out with the participation of a number of professors and experts in the field of urban planning and its validity order confirmed then its reliability was confirmed by Cronbach's Alpha method with a confidence level of $96 \%$. Subsequently, questionnaires and interviews were completed randomly in the site. Finally, the data were analyzed using SPSS software.

\section{Indicators of social impact assessment}

To identify the indicators and variables for assessing social impacts, suggested indicators of theorists and communities such as Inter organizational Committee on SIA (1994), Rabel Burdge (1999), Bureau of Reclamation (2001), Taylor (2004) and Finsterbusch (1981) are introduced.

Table1. Proposed criteria by experts

\begin{tabular}{|c|c|c|c|c|}
\hline $\begin{array}{l}\text { Inter Organizational } \\
\text { Committee on SIA } \\
\text { (1994) }\end{array}$ & $\begin{array}{l}\text { Burdge } \\
\text { (1999) }\end{array}$ & $\begin{array}{l}\text { Bureau of } \\
\text { Reclamation } \\
\text { (2001) }\end{array}$ & $\begin{array}{l}\text { Taylor } \\
(2004)\end{array}$ & $\begin{array}{l}\text { Finsterbusch } \\
\text { (1981) }\end{array}$ \\
\hline $\begin{array}{l}\text { Population } \\
\text { characteristics means } \\
\text { present population and } \\
\text { change as a result of } \\
\text { the proposed action }\end{array}$ & $\begin{array}{l}\text { Population impacts } \\
\text { means changes in } \\
\text { number, density and } \\
\text { distribution }\end{array}$ & $\begin{array}{l}\text { Population means } \\
\text { changes in number, } \\
\text { density and distribution } \\
\text { and resulting } \\
\text { composition }\end{array}$ & $\begin{array}{l}\text { Population } \\
\text { impacts means } \\
\text { changes in } \\
\text { number and } \\
\text { density }\end{array}$ & $\begin{array}{l}\text { Community inputs: labor, } \\
\text { natural resources, financial } \\
\text { resources, economic and } \\
\text { cultural facilities }\end{array}$ \\
\hline $\begin{array}{l}\text { Community and } \\
\text { institutional structure } \\
\text { refers to the size, } \\
\text { structure and level of } \\
\text { organization of local } \\
\text { government }\end{array}$ & $\begin{array}{l}\text { Community and } \\
\text { institutional } \\
\text { arrangements } \\
\text { means changes in } \\
\text { attitudes, values, } \\
\text { and in government } \\
\text { and employment }\end{array}$ & $\begin{array}{l}\text { Community } \\
\text { composition means } \\
\text { changes in image, } \\
\text { power structure, } \\
\text { conflicts with outsiders } \\
\text { and alteration in } \\
\text { present institutions }\end{array}$ & $\begin{array}{l}\text { Changing } \\
\text { people's life style, } \\
\text { Attitudes, beliefs } \\
\text { and values }\end{array}$ & $\begin{array}{l}\text { Social Outputs: Quality of Life } \\
\text { (employment, housing, } \\
\text { access to services, etc.), } \\
\text { social (appropriate social } \\
\text { relations, education, health, } \\
\text { good mental status, etc.), } \\
\text { Political (public participation, } \\
\text { freedom and civil rights, } \\
\text { equality and justice, etc.). }\end{array}$ \\
\hline $\begin{array}{l}\text { Political and social } \\
\text { resources refers to the } \\
\text { distribution of power } \\
\text { authority, interested } \\
\text { and affected parties } \\
\text { and leadership } \\
\text { capacity. }\end{array}$ & $\begin{array}{l}\text { Communities in } \\
\text { transition refers to } \\
\text { alterations in power } \\
\text { with the arrival of } \\
\text { different groups and } \\
\text { agendas }\end{array}$ & $\begin{array}{l}\text { Community attitudes, } \\
\text { identity and } \\
\text { institutional structures } \\
\text { means changes in } \\
\text { attitudes, values, local } \\
\text { government and } \\
\text { employment }\end{array}$ & $\begin{array}{l}\text { Change in social } \\
\text { organization }\end{array}$ & $\begin{array}{l}\text { Structures of the community: } \\
\text { general structures and } \\
\text { concrete social structures } \\
\text { (government, labor market, } \\
\text { commodity market, credit } \\
\text { market, educational system, } \\
\text { system Welfare, religious and } \\
\text { cultural institutions, voluntary } \\
\text { associations, the planning } \\
\text { system, etc.) }\end{array}$ \\
\hline $\begin{array}{l}\text { Individual and family } \\
\text { changes refers to } \\
\text { factors that influence } \\
\text { daily life, to include } \\
\text { attitudes, values, } \\
\text { perceptions and social } \\
\text { networks }\end{array}$ & $\begin{array}{l}\text { Individual and family } \\
\text { level impacts means } \\
\text { changes in family } \\
\text { and individual } \\
\text { relations and } \\
\text { conduct of daily life }\end{array}$ & $\begin{array}{l}\text { Individuals and } \\
\text { families means } \\
\text { changes in family } \\
\text { structure, social } \\
\text { relations and } \\
\text { perceptions of change } \\
\text { in daily life }\end{array}$ & & $\begin{array}{l}\text { Activities of the community: } \\
\text { Understand the activities that } \\
\text { individuals perform in various } \\
\text { areas of work, personal life, } \\
\text { family and social life }\end{array}$ \\
\hline Community resources & Community & Community & & \\
\hline
\end{tabular}




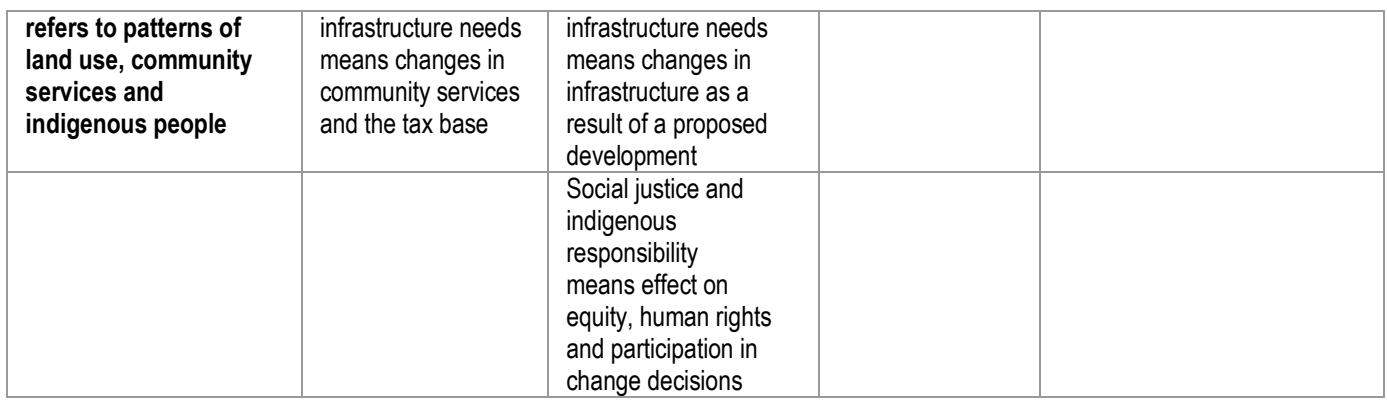

A panel of experts, government officials and stakeholders (residents, employees and space users) invited to participate in the process of developing a list of critical factors for evaluating the social impacts of reconstruction and renewal projects in historic site. During the indepth interviews and fill in the questionnaire they provided the list of critical factors (table 2).

Table2. List of obtained variables

\begin{tabular}{|c|c|c|c|}
\hline Indicator & Cause of measurement & $\begin{array}{l}\text { Measurement } \\
\text { method }\end{array}$ & Affected group \\
\hline Quality of Life & $\begin{array}{l}\text { Reasons for leaving the } \\
\text { neighborhood }\end{array}$ & $\begin{array}{l}\text { Questionnaire } \\
\text { and interview }\end{array}$ & Residents \\
\hline Immigration & Demographic Impact Assessment & $\begin{array}{l}\text { Questionnaire } \\
\text { and interview }\end{array}$ & Residents \\
\hline Environmental health & $\begin{array}{l}\text { The impact of the plan on } \\
\text { neighborhood health }\end{array}$ & $\begin{array}{l}\text { Questionnaire, } \\
\text { interview and } \\
\text { observation }\end{array}$ & $\begin{array}{l}\text { Residents and Neighborhood } \\
\text { shopper }\end{array}$ \\
\hline Safety and security & Neighborhood Security & $\begin{array}{l}\text { Questionnaire } \\
\text { and interview }\end{array}$ & $\begin{array}{l}\text { Residents and Neighborhood } \\
\text { shopper }\end{array}$ \\
\hline Car access & $\begin{array}{l}\text { Identify the changes caused by } \\
\text { restricting cars }\end{array}$ & Scrolling the trip & Drivers \\
\hline The presence of tourists & $\begin{array}{l}\text { The inclination of travelers to attend } \\
\text { the historic neighborhood }\end{array}$ & interview & $\begin{array}{l}\text { Tourists and Neighborhood } \\
\text { shopper }\end{array}$ \\
\hline Relations with neighbors & $\begin{array}{l}\text { Determine the amount of social } \\
\text { communication }\end{array}$ & $\begin{array}{l}\text { Questionnaire } \\
\text { and interview }\end{array}$ & $\begin{array}{l}\text { Residents and Neighborhood } \\
\text { shopper }\end{array}$ \\
\hline $\begin{array}{l}\text { Desire to leave the } \\
\text { neighborhood }\end{array}$ & $\begin{array}{l}\text { Estimated loss of social and human } \\
\text { capital }\end{array}$ & $\begin{array}{l}\text { Questionnaire } \\
\text { and interview }\end{array}$ & Government and Residents \\
\hline $\begin{array}{l}\text { The desire to renewal the } \\
\text { historic site }\end{array}$ & $\begin{array}{l}\text { Understanding the causes of the lack } \\
\text { of renewal plans of the historic site }\end{array}$ & $\begin{array}{l}\text { Questionnaire } \\
\text { and interview }\end{array}$ & Government and Residents \\
\hline Change Job Opportunities & $\begin{array}{l}\text { Identify the prospect of economic } \\
\text { prosperity and social conditions }\end{array}$ & interview & Neighborhood shopper \\
\hline Participation & $\begin{array}{l}\text { Impact of project exploitation on } \\
\text { people's motivation }\end{array}$ & interview & $\begin{array}{l}\text { Government, Residents and } \\
\text { Neighborhood shopper }\end{array}$ \\
\hline
\end{tabular}

\section{Case Studies}

The case of reconstruction project of Jameh Mosque Street as a part of historic site in Yazd will be used to test the list of indicators. 


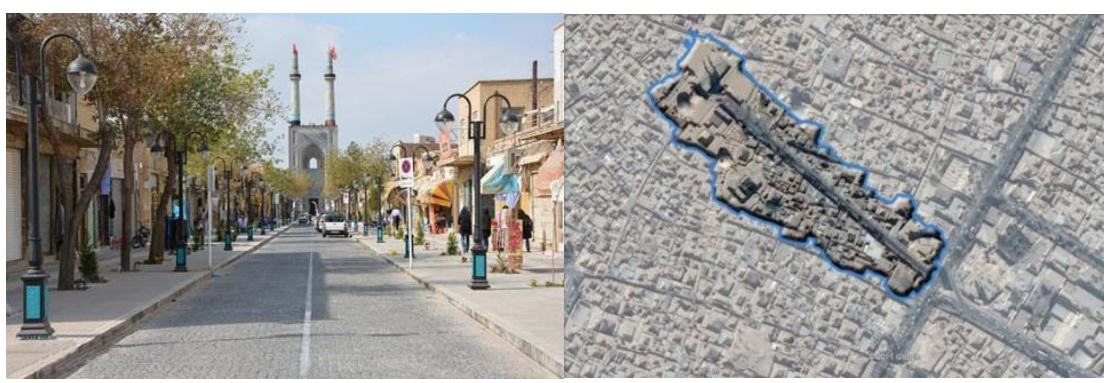

Figure1. Jameh Mosque Street

\section{Identify impacts and attributes}

The SIA's variables help the researcher to list a possible impact based on the role of these variables on the social context of case study also the list is on the impact of "SIA variables" on "sensitive areas" within the geographical and human geographic ranges of planned action and consideration of "important stakeholders" (Simpson, 2000).

To identify the influential factors in assessing the social effects of the projects in historic site, the features of the possible impacts must be identified. This attribute of probabilistic effects is measured by the effects of the Jameh street project and scored with AHP method in the Expert Choice software. The output is the priority of these parameters.

\section{Building the AHP Models}

In order to prioritize the characteristics of the criteria for assessing the social impacts of historic site projects, a hierarchy tree is developed. The model consist of 8 alternatives (Variable attributes) and 13 indicators (most important impacts of Jameh street). The elements of hierarchy tree is presented in table 3 . The goal is exist at the top of the control hierarchy for the model. The goal is to identify and prioritize influential characteristic of the criteria to assess social impacts of urban projects in historic site. The 13 indicators employed for the analysis. These indicators are prepared according to the technical criteria and in accordance with the context of the project (historical context of Yazd city). It must be accepted that the selection of impacts and attributes is a collaborative effort made in the context of the value system (Fazeli, 2012) and they can be defined in follows statements.

The impacts that are likely to occur and the extent of their effects are high and those that are less likely to occur, but the extent of their effects is high, are more important.

The effects on the most vulnerable groups, such as the elderly, the disabled and children, are prioritized

The effects that have long affected the environment are prioritized.

The effects that can produce additional and more cumulative effects are prioritized.

The effects that can have security implications or challenge overall policies are priorities.

The effects that are causing conflict and tension on the basis of social sensitivities are more important.

The effects that bring about huge economic costs to society are prioritized

The effects that will contribute to the improvement of the historic site as a valuable area of Yazd are prioritized.

The impacts that promote social values among residents of the Jameh mosque neighborhood.

Table3. Domain Matrix for Jameh Mosque Street 


\begin{tabular}{|c|c|c|c|c|c|c|c|c|}
\hline Impact Attributes & 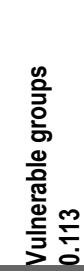 & 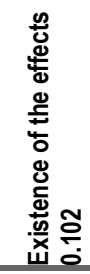 & 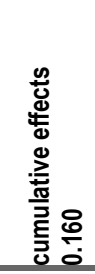 & 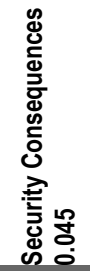 & 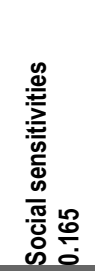 & 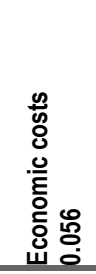 & 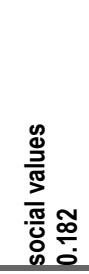 & 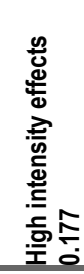 \\
\hline $\begin{array}{l}\text { Return of former residents to the } \\
\text { neighborhood } \\
\text { (L: } 0.026)\end{array}$ & 0.086 & 0.716 & 0.350 & 0.096 & 0.364 & 0.175 & 1.00 & 0.545 \\
\hline $\begin{array}{l}\text { Reduced noise pollution } \\
(\mathrm{L}: 0.064)\end{array}$ & 1.00 & 0.634 & 0.975 & 0.125 & 0.147 & 0.596 & 0.426 & 0.514 \\
\hline $\begin{array}{l}\text { Facilitate the movement of } \\
\text { pedestrians } \\
(\mathrm{L}: 0.167)\end{array}$ & 0.514 & 0.469 & 0.637 & 0.160 & 0.642 & 0.341 & 0.656 & 1.00 \\
\hline $\begin{array}{l}\text { Reduce air pollution } \\
\text { (L: 0.039) }\end{array}$ & 1.00 & 0.491 & 0.642 & 0.090 & 0.107 & 0.086 & 0.264 & 0.105 \\
\hline $\begin{array}{l}\text { The aesthetic quality of the } \\
\text { landscape } \\
\text { (L: 0.051) }\end{array}$ & 0.139 & 0.379 & 0.439 & 0.176 & 0.881 & 0.166 & 0.784 & 1.00 \\
\hline $\begin{array}{l}\text { Increasing economic prosperity } \\
\text { (L: } 0.072)\end{array}$ & 0.192 & 0.634 & 1.00 & 0.212 & 0.238 & 0.279 & 0.731 & 0.988 \\
\hline $\begin{array}{l}\text { Disruption in the movement of } \\
\text { residents with vehicle } \\
\text { (L: } 0.036)\end{array}$ & 0.832 & 0.339 & 0.367 & 0.142 & 0.474 & 0.303 & 0.367 & 1.00 \\
\hline $\begin{array}{l}\text { Increasing people's security } \\
(\mathrm{L}: 0.120)\end{array}$ & 1.00 & 0.288 & 0.497 & 0.468 & 0.590 & 0.164 & 0.994 & 0.393 \\
\hline $\begin{array}{l}\text { Constraints on the provision of } \\
\text { infrastructure } \\
(\mathrm{L}: 0.033)\end{array}$ & 0.271 & 0.273 & 0.344 & 0.335 & 0.194 & 1.00 & 0.050 & 0.486 \\
\hline $\begin{array}{l}\text { Revitalizing historic site } \\
(\mathrm{L}: 0.126)\end{array}$ & 0.114 & 0.323 & 0.814 & 0.082 & 1.00 & 0.249 & 0.784 & 0.848 \\
\hline $\begin{array}{l}\text { Improving the social relationships } \\
\text { of residents } \\
\text { (L: } 0.208)\end{array}$ & 0.130 & 0.212 & 0.468 & 0.062 & 1.00 & 0.051 & 0.788 & 0.382 \\
\hline
\end{tabular}




\begin{tabular}{|l|l|l|l|l|l|l|l|l|}
\hline $\begin{array}{l}\text { Increasing citizen participation } \\
\text { (L: } \mathbf{0 . 0 2 4 )}\end{array}$ & 0.133 & 0.244 & 0.683 & 0.276 & 0.736 & 0.295 & 1.00 & 0.569 \\
\hline $\begin{array}{l}\text { Preservation of cultural heritage } \\
\text { (L: } \mathbf{0 . 0 3 3 )}\end{array}$ & 0.138 & 0.750 & 0.353 & 0.122 & 0.566 & 0.137 & 0.936 & 1.00 \\
\hline
\end{tabular}

According to the result of the model, the impacts that promote social values among residents of historic site are the most influential factor for assess social impacts of this area and Followed by the intensity of the impact, Social sensitivities and cumulative effects. Security consequences and Economic costs are ranked as the least influential factors. The result presented in figure 2 .
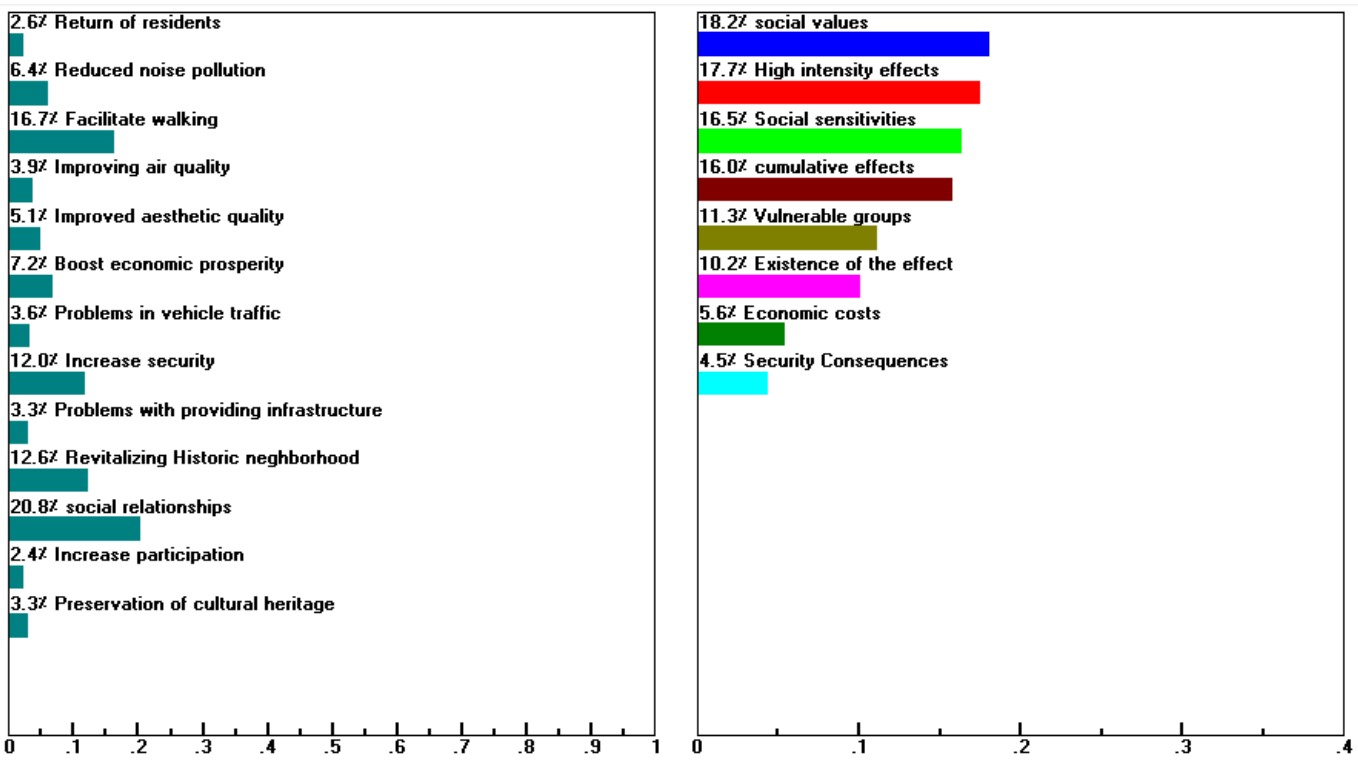

Figure2. Graphical results of Model

\section{Conclusions}

Social impact assessment is necessary for every change in the city to inform decision makers about the consequences of their decisions. The social impacts of projects in historic site are different than the other parts of the city because of rich identity and social values in this area so it is essential to identify and prioritize the significant features of the historic site and to be used in the SIA's process based on the score of each other. The first important factor is to adhere to the principles, views and social values of the inhabitants of the historic neighborhood and any changes that cause a change in the lifestyle of these people must be applied carefully. The second most influential factor in evaluating historic neighborhood projects is paying attention to the severity of the effect. The possibility of compensating for the negative consequences in this area is low and sometimes leads to the loss of historical value or social and cultural life. The third one is paying attention to the problems that residents have a special sensitivity towards them such as racial and religious prejudice, gender inequality and beliefs. In the historic site, this factor is so strong that it can prevent the implementation of the project. The fourth most important factor in assessing social impacts is to pay attention to the effects that lead to subsequent consequences. These next implications usually have effect greater than the initial and the physical and spatial capacities of historic site may not be ready to face these consequences. At last but not least, attention to vulnerable groups, the sustainability of the effects 
over time, economic costs and security consequences are the significant factors for historic neighborhood. Finally, it is essential to determine the characteristics of each effects at the stage of predicting possible effects in SIA's process to determine the importance of each effect base on scores earned by their prioritization and decisions are made to enhance or eliminate the effect.

\section{Reference}

[1] Barrow, C. J. (2010). How is environmental conflict addressed by SIA? Environmental Impact Assessment Review, 30(5), 293301.

[2] Burdge, Rabel J (1999), A Community Guide to Social Impact Assessment: Revised Edition. Social Ecology Press, Middleton, Wisconsin, PO Box 53562-0863) ISBN 0-941042-17-0.

[3] Bureau of Reclamation (2001), Social Analysis Manuel: Volume 2, Social Analyst's Guide to Doing Social Analysis (Technical Service Center-DFC, Denver, CO 80225-0007).

[4] Finsterbusch, Kurt. \& C. P. Wolf (1981), "Methodology of Social Impact Assessment", Hutchinson Ross Publishing Company.

[5] Glasson, J. (2000). Socio-economic impacts 1: overview and economic impacts, in: Morris, P. and Therivel, R. (2000), Methods of Environmental Impact Assessment, Spon Press, London and New York.

[6] Swensen, G. (2012).Integration of historic fabric in new urban development -A Norwegian casestudy.Landscape and Urban Planning, 107, 380-388.

[7] The Inter organizational Committee on Guidelines and Principles for Social Impact Assessment (2004), "Guidelines and Principles For Social Impact Assessment

[8] Tilt, Bryan; Braun, Yvonne; He, Daming (2009). "Social impacts of large dam projects: A comparison of international case studies and implications for best practice". Journal of Environmental Management. 90: S250. doi:10.1016/j.jenvman.2008.07.030.

[9] Taylor Nicholas \& Hobson Bryan \& Colin Goodrich (2004), "Social Assessment: Theory, process and Techniques", social ecology press.

[10] Simpson, Gray (2000). "Social Impact Assessment tools for mitigation and project development", In Goldman.

[11] Vanclay, F. (2003a). International principles for social impact assessment. Impact Assessment and Project Appraisal, 21 (1) 5-11.

[12] Vanclay, F. (2006). Principles for social impact assessment: a critical comparison between the international and US documents. Environmental Impact Assessment Review, 26 (1), 3-14.

[13] Fazeli, Mohammad (2012). Social Impact Assessment, Second Edition, Deputy of Social and Cultural Affairs, Social and Cultural Studies Department, Tisa Publishing. 